\title{
Randomized prospective comparison of long-term results of onlay and sublay mesh repair techniques for incisional hernia
}

\author{
Barıș Sevinç ${ }^{1}$, Ahmet Okuș 2 , Serden Ay², Nergis Aksoy ${ }^{3}$, Ömer Karahan ${ }^{4}$
}

ABSTRACT Objective: Incisional hernia is a significant problem after laparotomy, and there is still no consensus on an ideal treatment method. The aim of this study was to compare the results of onlay and sublay mesh repair techniques.

Material and Methods: In this randomized prospective trial, 100 patients were divided into two groups: onlay and sublay groups. Recurrences were evaluated by performing a physical examination.

Results: The median follow-up was 37.1 (26.6 to 46.5) months. In the onlay group, the mean operation time was significantly shorter. However, in terms of postoperative pain and wound complications, the sublay group had significantly better results. The recurrence rates were found to be similar in both groups ( $6 \%$ in the onlay group and $2 \%$ in the sublay group).

Conclusion: In the treatment of incisional hernia, sublay mesh repair is superior to onlay mesh repair in terms of postoperative pain and wound complications. Both techniques have similar recurrence rates.

Keywords: Incisional hernia, mesh repair, onlay, sublay

Cite this paper as:

Sevinç B, Okuş A, Ay S, Aksoy

$\mathrm{N}$, Karahan 0 . Randomized prospective comparison of long-term results of onlay and sublay mesh repair techniques for incisional hernia. Turk J Surg 2018; 34: $17-20$.

'Department of General Surgery, Medical Park Uşak Hospital, Uşak, Turkey

2Department of General Surgery, Karatay University School of Medicine, Konya, Turkey

${ }^{3}$ Department of General Surgery, Konya Training and Research

Hospital, Konya, Turkey

${ }^{4}$ Department of General Surgery, Uşak University School of Medicine, Uşak, Turkey

Address for Correspondence Barış Sevinç

e-mail:drbarissevinc@gmail.com

Received:21.09.2016

Accepted: 08.02.2017

Available Online Date: 04.01.2018

(c) Copyright 2018

by Turkish Surgical Association

Available online at

www.turkjsurg.com

\section{INTRODUCTION}

Incisional hernia is a significant complication after laparotomy; its incidence ranges between 10\% and $20 \%$ (1-4). This common problem can result in bowel strangulation, pain, and enterocutaneous fistula, and it affects the quality of life. The results of repair techniques vary widely. High recurrence rates have been reported for suture techniques, whereas mesh placement can reduce recurrence (5-10). In mesh repair, one of the most important problems is the placement of the mesh. Some techniques are reported to be associated with particularly high rates of some complications, such as recurrence, wound infection, and fistula $(11,12)$. In the literature, several studies compare mesh and suture repair techniques, open and laparoscopic repair techniques, and mesh type as well as the plane in which the mesh should be placed. Currently, there is no consensus regarding the abdominal plane in which the mesh should be placed (13).

The aim of this study was to compare the early and late results of onlay and sublay mesh repair techniques.

\section{MATERIAL AND METHODS}

This randomized prospective study was conducted between January 2011 and December 2014. Permission was acquired from the Selçuk University School of Medicine Clinical Trials Ethical Committee. All procedures were in accordance with the ethical standards of the responsible committee on human experimentation and with the Helsinki Declaration of 1975 as revised in 2008. The trial is registered at clinicaltrials.gov, and the ID is NCT02314091. Patients who were admitted at the outpatient clinic with incisional hernia were evaluated. To prevent bias, only patients with midline incisional hernias were included. Patients with a body mass index (BMI) of above $40 \mathrm{~kg} / \mathrm{m}^{2}$, an American Society of Anesthesiologists score (ASA) of 4, or severe pulmonary or cardiac disease were not included. The remaining patients who agreed to be involved and signed the informed consent form were randomized into two groups: onlay group and sublay group. After the initial evaluation, 100 patients were included and were randomized to each group by the closed envelope method. The patients' demographic data, BMI, diameter of fascial defects, operation time (from first incision to dressing), visual analog scale (VAS) scores at the second and $24^{\text {th }}$ hours, length of hospital stay, drain takeoff time, postoperative complications, and recurrences were recorded. The fascial defect diameter was measured intraoperatively and is presented in $\mathrm{cm}^{2}$. All operations were performed according to the elective standard. There were no emergency operations.

\section{Operative Technique}

All operations were performed under general anesthesia, and no antibiotic was administered. After excision of the old incision scar, the hernia sac was dissected and the peritoneal cavity was opened. Adhesions between visceral organs and the abdominal wall were dissected. The peritoneal surface was closed with an absorbable continuous suture. 
In sublay mesh repair, the posterior aspect of the rectus muscle was dissected and a polypropylene mesh was placed below the rectus muscle. The mesh was fixed to the posterior rectus sheet using polypropylene sutures. If the fascia could be closed without tension, it was sutured to the closest part of the mesh. In all patients, the mesh was placed so that at least 5 $\mathrm{cm}$ overlapped the fascia at all sides.

In onlay mesh repair, the peritoneal surface and fascia were closed with polypropylene sutures. The subcutaneous tissue was released to place the mesh on the anterior aspect of the fascia. The mesh was placed on the anterior aspect of the fascia with at least $5 \mathrm{~cm}$ overlapping the fascial edges at all sides and was fixed to the fascia with polypropylene sutures. In all patients, a vacuum drain was placed above the mesh, and the skin and subcutaneous tissue were closed with absorbable sutures.

After the operations, the VAS scores were recorded at the second and $24^{\text {th }}$ hour. The vacuum drains were removed when the daily drainage was below $50 \mathrm{~mL}$. Patients were followed up at the first and second weeks; at the first, the third, and the sixth months; and then yearly. At each follow-up visit, the patients were examined for recurrences; when in doubt, recurrence was confirmed by ultrasonography. At the termination of the study, all patients were called for a follow-up visit and all were evaluated by a physical examination. During the followup visits, the patients were examined by a blinded attending surgeon. A flow chart of the study is presented in Figure 1. Wound infection was defined as erythema and suppuration around the wound. Any collection at the wound was drained and examined for bacterial contamination.

\section{Statistical Analysis}

Statistical analysis was performed using Statistical Package for the Social Sciences 22.0 (IBM Corp.; Armonk, NY, USA) software. The Student's t test was used to compare quantitative parametric data, and the Mann-Whitney $U$ Test was used to compare quantitative non-parametric data. The chi-square test was used to compare qualitative data. Statistical significance was accepted at 0.05 .

\section{RESULTS}

One hundred patients were included in the study, with a mean age of $55.4 \pm 11.9$. Of the patients, $64 \%$ were female and $36 \%$ were male. The groups were similar in terms of age and gender. The mean BMI of all patients was $25.9 \pm 3.5 \mathrm{~kg} / \mathrm{m}^{2}$, and the groups were similar in terms of BMI. The mean hernia defect was also similar in both groups $\left(73.4 \pm 66.3 \mathrm{~cm}^{2}\right)$. The median follow-up of the study was 37.1 (26.6 to 46.5 ) months. The demographic data are presented in Table 1.

The mean operation time was $65.3 \pm 17.2$ minutes; this was significantly shorter in the onlay group then in the sublay group $(56.7 \pm 15.7 \mathrm{~min}$ and $73.9 \pm 14.2 \mathrm{~min}$, respectively) $(\mathrm{p}<0.001)$ (Figure 2). The mean length of hospital stay was $3.36 \pm 1.9$ days in the onlay group and $3.52 \pm 2.6$ days in the sublay group. The mean length of hospital stay was similar in both groups $(p=0.734)$.

Postoperative pain was evaluated by VAS at the second and $24^{\text {th }}$ hours. At the second hour, the mean VAS score was $7.38 \pm 1$ in the onlay group and $6.9 \pm 1$ in the sublay group. The mean

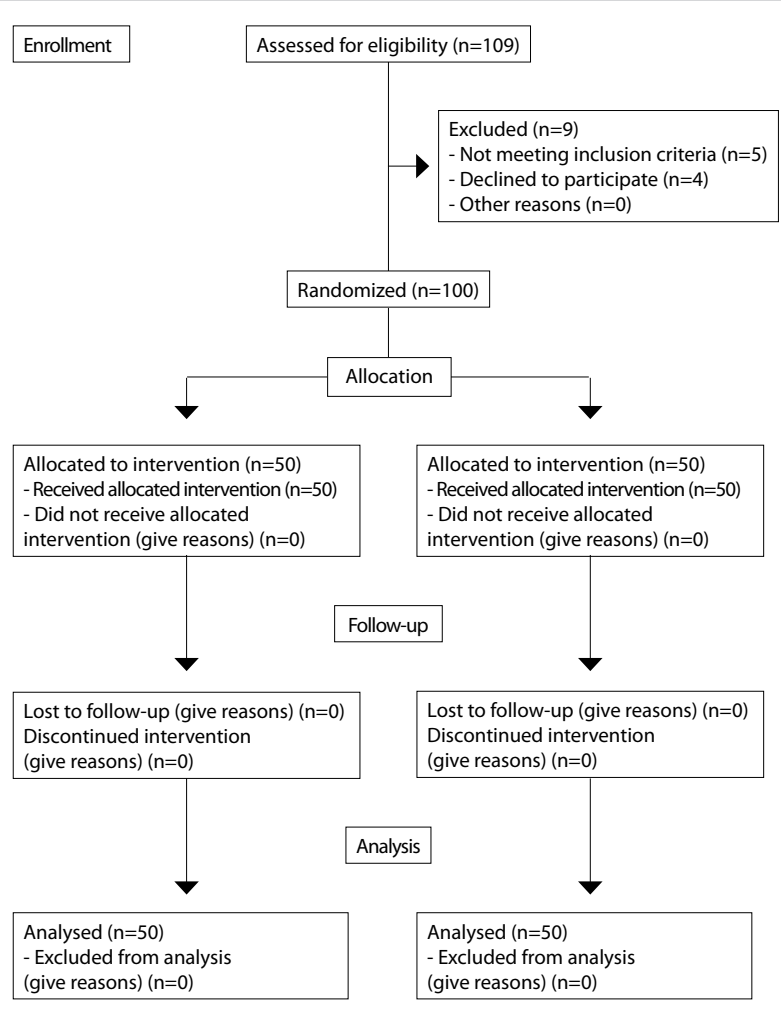

Figure 1. Flow diagram

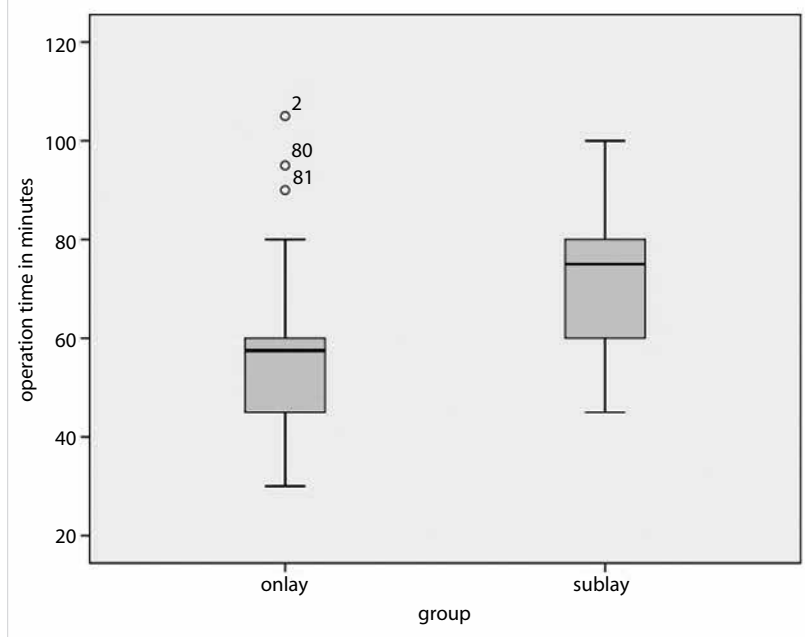

Figure 2. Comparison of operation times

sublay group $(p=0.031)$. Similarly, at the $24^{\text {th }}$ hour, the mean VAS score was significantly lower in the sublay group $(2.5 \pm 0.8$ vs. $2.9 \pm 1$, respectively) $(p=0.010)$.

In all operations, a vacuum drain was placed. The drains were removed when the daily outcome was below $50 \mathrm{ml}$. The mean drain removal time was $5.4 \pm 2.3$ days in the onlay group and $3.2 \pm 1.1$ days in the sublay group $(p=0.001)$. The mean operation time, length of hospital stay, VAS scores, and drain removal time are presented in Table 2 .

The overall postoperative wound complication rates were significantly lower in the sublay group: $24 \%$ (n: 12$)$ in the onlay group and $8 \%(n: 4)$ in the sublay group $(p=0.029)$. The most 
Table 1. Demographic data of the patients

\begin{tabular}{|c|c|c|c|c|}
\hline & & Onlay group & Sublay group & $\mathbf{p}$ \\
\hline $\mathrm{Age}^{\mathrm{a}}$ & & $55.9 \pm 11.8$ & $55.9 \pm 12.1$ & $0.703^{*}$ \\
\hline \multirow[t]{2}{*}{ Gender $^{b}$} & Male & $22(44)$ & $14(28)$ & \multirow[t]{2}{*}{$0.096^{* *}$} \\
\hline & Female & $28(56)$ & $36(72)$ & \\
\hline $\mathrm{BMI}\left(\mathrm{kg} / \mathrm{m}^{2}\right)($ mean $\pm \mathrm{SD})$ & & $25.5 \pm 3.5$ & $26.4 \pm 3.3$ & $0.170^{*}$ \\
\hline \multirow[t]{3}{*}{ ASA score } & 1 & $8(16)$ & $5(10)$ & \multirow[t]{3}{*}{$0.643^{* *}$} \\
\hline & 2 & $22(44)$ & $25(50)$ & \\
\hline & 3 & $20(40)$ & $20(40)$ & \\
\hline Diameter of the hernia defect $(\mathrm{cm} 2)($ mean $\pm S D)$ & & $61.6 \pm 58.3$ & $85.1 \pm 72.1$ & $0.077^{*}$ \\
\hline Follow-upc (months) & & $35.9(26.6-45.7)$ & $37.9(27.4-46.5)$ & $0.097^{* * *}$ \\
\hline
\end{tabular}

Table 2. Comparisons of groups in terms of operation time, length of hospital stay, VAS scores, and drain removal time

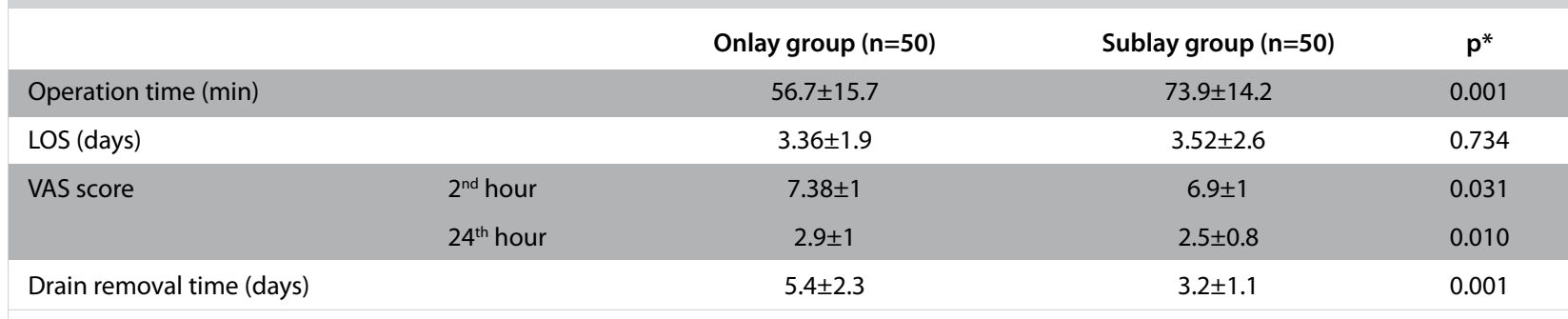

SD: standard deviation; LOS: length of hospital stay;VAS: visual analoque scale *Student's t test. Datas were presented as mean+ Standard deviation

Table 3. Postoperative wound complications

\begin{tabular}{|lccc|}
\hline & $\begin{array}{c}\text { Onlay group } \\
(\mathbf{n}=50)\end{array}$ & $\begin{array}{c}\text { Sublay group } \\
(\mathbf{n}=50)\end{array}$ & $\mathbf{p}^{*}$ \\
\hline Wound infection & $2(4)$ & $2(4)$ & 1.00 \\
\hline Seroma & $7(14)$ & $1(2)$ & 0.027 \\
\hline Hematoma & $3(6)$ & $1(2)$ & 0.307 \\
\hline Overall & $12(24)$ & $4(8)$ & 0.029 \\
\hline${ }^{*}$ Chi-square test ; $\mathbf{n}(\%)$ & & & \\
\hline
\end{tabular}

common complication was seroma formation in $8(8 \%)$ patients, followed by wound infection in 4 (4\%) patients and hematoma in 4 patients. The complications are presented in Table 3. During the study period, no patients died due to the surgery. Only one patient died from myocardial infarction after the $3^{\text {rd }}$ year control.

Within the median follow-up of 37.1 months, the groups were similar in terms of recurrence. The recurrence rates were $6 \%$ $(\mathrm{n}: 3)$ in the onlay group and $2 \%(\mathrm{n}: 1)$ in the sublay group $(p=0.307)$.

\section{DISCUSSION}

Incisional hernia remains a major problem after laparotomy. Previously used open primary suture techniques had high recurrence rates and complication rates as high as $44 \%$ (14). Although many techniques are defined for the repair of incisional hernias, in open mesh repair techniques, the location where the mesh should be placed is still under debate. Despite reports that show no association of complications or re- currence rate with the location where the mesh is placed, this controversy is ongoing (15-17).

Postoperative wound complications are one of the major problems following mesh repair of incisional hernia. Wound complications such as infection, seroma, and hematoma increase the risk of recurrence by 4.1, 3.4, and 3.5 times, respectively (15). In a randomized prospective study, Venclauskas et al. (18) reported that onlay mesh repair requires less time than sublay mesh repair. Moreover, they reported that sublay mesh repair had a lower postoperative complication rate. However, in a cohort study, Gleysteen (17) reported that onlay and sublay mesh repair techniques have similar wound complication rates (16\% and $12 \%$, respectively). In a recent meta-analysis, sublay mesh repair was reported as having the least wound infection rate than onlay, inlay, and underlay mesh placement [Odds Ratio: 0.449 (95\% Cl, $0.12-1.16)$ ] (19). In the present study, the mean operation time was shorter in the onlay group and the mean complication rate was lower in the sublay group.

In the literature, postoperative pain has been reported to be much greater using suture techniques. Considering onlay and sublay mesh repair techniques, Venclauskas et al. (18) reported similar postoperative pain scores both at rest and during physical activity. However, Den Hartog et al. (20) reported sublay mesh repair to cause less pain than onlay mesh repair. Similarly, our results show that the sublay group had lower VAS scores at the second and $24^{\text {th }}$ hours.

The recurrence rates by onlay and sublay mesh repair techniques remain controversial. According to Başoğlu et al. (15) the recurrence rates are similar by onlay and sublay mesh re- 
pair techniques. In a randomized controlled trial with a 5-year follow-up, Weber et al. (21) reported that sublay mesh repair has a significantly higher recurrence rate than onlay mesh repair ( $20 \%$ vs. $12 \%$, respectively). Den Hartog et al. (20) reported recurrence rates of $7.4 \%$ by onlay mesh repair and $13.6 \%$ by sublay mesh repair. Moreover, Venclauskas et al. (18) reported recurrence rates of $10.5 \%$ using onlay mesh repair and $2 \%$ using sublay mesh repair. In a meta-analysis, Mathes et al. (22) reported no difference in recurrence rates. Similarly, in the present study, the recurrence rates using onlay and sublay mesh repair techniques were found to be similar: $6 \%$ using onlay mesh repair and $2 \%$ using sublay mesh repair.

The main limitation of this study is the relatively low numbers of patients in both groups. To identify a difference of $8 \%$ in the recurrence rate, there should be 375 patients in each group. This number of patients can only be achieved by multicenter studies. As the main goal of the study was to compare the recurrence and complication rates between onlay and sublay mesh repair techniques, we did not evaluate the pain scores, time of return to activity, or long-term patient satisfaction. However, we believe that with more than three years of followup, our results are valuable and reliable.

\section{CONCLUSIONS}

In this prospective trial with a median follow-up of 37 months, sublay mesh repair was found to be superior to onlay mesh repair in terms of postoperative pain and complications and equal in terms of recurrence rate.

Ethics Committee Approval: Ethics committee approval was received for this study from the ethics committee of Selçuk University School of Medicine Clinical Trials Ethical Committee.

Informed Consent: Written informed consent was obtained from patients who participated in this study.

Peer-review: Externally peer-reviewed.

Author Contributions: Concept - B.S., A.O., Ö.K.; Design - B.S., A.O., S.A.; Supervision - A.O., Ö.K.; Resource - B.S., A.O., N.A.; Materials - B.S., S.A., N.A.; Data Collection and/or Processing - B.S., A.O., N.A.; Analysis and/ or Interpretation - B.S., A.O.; Literature Search - B.S., S.A., N.A.; Writing Manuscript - B.S., A.O.; Critical Reviews - B.S., Ö.K.

Conflict of Interest: No conflict of interest was declared by the authors.

Financial Disclosure: The authors declared that this study has received no financial support.

\section{REFERENCES}

1. Kingsnorth $A$, LeBlanc K. Hernias: inguinal and incisional. Lancet 2003; 362: 1561-1571. [CrossRef]

2. Mudge M, Hughes LE. Incisional hernia: a 10 year prospective study of incidence and attitudes. Br J Surg 1985; 70: 70-71. [CrossRef]

3. Burger J, van 'tRiet $M$, Jeekel J. Abdominal incisions: techniques and postoperative complications. Scand J Surg 2003; 91: 315-

\section{1. [CrossRef]}

4. Kurzer M, Kark A, Selouk S, Belsham P. Open mesh repair of incisional hernia using a sublay technique: long-term follow up. World J Surg 2008; 32: 31-36. [CrossRef]

5. Burger JW, Liujendijk RW, Hop WC Halm JA, Verdaasdonk EG, Jeekel J. Long-term follow-up of a randomized controlled trial of suture versus mesh repair of incisional hernia. Ann Surg 2004; 240: 578-583. [CrossRef]

6. Cassar K, Munro A. Surgical treatment of incisional hernia. $\mathrm{Br} \mathrm{J}$ Surg 2002; 89: 534-545. [CrossRef]

7. Luijendjik R, Hop WCJ, van den Tol P, de Lange DC, Braaksma MM, IJzermans JN. A comparison of suture repair with mesh repair for incisional hernia. N Engl J Med 2000; 343: 392-398. [CrossRef]

8. Paul A, Korenkov M, Peters S. Unacceptable results of the Mayo procedure for repair of abdominal incisional hernias. Eur J Surg 1998; 164: 361-367. [CrossRef]

9. Israelson LA, Smedberg S, Montgomery A, Nordin P, Spangen L. Incisional hernia repair in Sweden 2002. Hernia 2006; 10: 258261. [CrossRef]

10. Korenkov M, Paul A, Sauerland E, Neugebauer E, Arndt M, Chevrel $J P$, et al. Classification and surgical treatment of incisional hernia: results of an expert's meeting. Langenbecks Arch Surg 2001; 386: 65-73. [CrossRef]

11. De Vries Reilingh TS, van Geldere D, Langenhorst B, de Jong D, van der Wilt GJ, vanGoor $\mathrm{H}$, et al. Repair of large midline incisional hernias with polypropylene mesh: comparison of three operative techniques. Hernia 2004; 8: 56-59. [CrossRef]

12. Langer C, Schaper A, Liersch T, Kulle B, Flosman M, Füzesi L, et al. Prognosis factors in incisional hernia surgery: 25 years of experience. Hernia 2005; 9: 16-21. [CrossRef]

13. Kokotovic D, Gögenur I, Helgstrand F. Substantial variation among hernia experts in the decision for treatment of patients with incisional hernia: a descriptive study on agreement. Hernia 2017; 21: 271-278. [CrossRef]

14. Sauerland S, Schmedt CG, Lein S, Leibl BJ, Reinhard Bittner R. Primary incisional hernia repair with or without polypropylene mesh: a report on 384 patients with 5-year follow-up. Langenbecks Arch Surg 2005; 390: 408-412. [CrossRef]

15. Basoglu M, Yildirgan MI, Yilmaz I, Balik A, Celebi F, Atamanalp SS, et al. Late complications of incisional hernias following prosthetic mesh repair. Acta Chir Belg 2004; 104: 425-428.

16. Vidovic D, Jurisic D, Franjic B D, Glavan E, Ledinsky M, Beslin MB. Factors affecting recurrence after incisional hernia repair. Hernia 2006; 10: 322-325. [CrossRef]

17. Gleysteen J.J. Mesh-Reinforced Ventral Hernia Repair, Preference for 2 Techniques. Arch Surg 2009; 144: 740-745. [CrossRef]

18. Venclauskas L, Maleckas A, Kiudelis M. One-year follow-up after incisional hernia treatment: results of a prospective randomized study. Hernia 2010; 14: 575-582. [CrossRef]

19. Holihan JL, Nguyen DH, Nguyen MT, Mo J, Kao LS, Liang MK. Mesh Location in Open Ventral Hernia Repair: A Systematic Review and Network Meta-analysis. World J Surg 2016; 40: 89-99. [CrossRef]

20. Den Hartog D, Dur AH, Tuinebreijer WE, Kreis RW. Open surgical procedures for incisional hernias. Cochrane Database Syst Rev 2008; 16: CD006438. [CrossRef]

21. Wéber G, Baracs J, Horváth OP. "Onlay" mesh provides significantly beter results than "sublay" reconstruction. Prospective randomized multicenter study of abdominal wall reconstruction with sutures only, or with surgical mesh--results of a five-years follow-up. Magy Seb.2010; 63: 302-311. [CrossRef]

22. Mathes $T$, Walgenbach $M$, Siegel R. Suture Versus Mesh Repair in Primary and Incisional Ventral Hernias: A Systematic Review and Meta-Analysis. World J Surg 2016; 40: 826-835. [CrossRef] 